\title{
O vírus da liquidez
}

\section{The liquidity virus}

\section{Augusto Sérgio São Bernardo}

Universidade do Estado da Bahia (Salvador). Bahia, Brasil.serginho.bernardo@hotmail.com

É tempo de mudanças rápidas e temporárias e quase nada pode ser eternizado. Tudo tem que ser breve e sem consistência. Qualquer coisa que demore é sinal de atraso e insegurança. O conceito de liquidez vige na imaginação das pessoas como uma senha para sobrevivência no mundo de hoje. Dinheiro líquido, sexo líquido, poder líquido, consumo líquido, identidade líquida, comunidades líquidas, ideologias líquidas, ética líquida, amores líquidos... Nada é tão fascinante e amedrontador quanto a ideia de algo concreto e duradouro. Mesmo quem afirma a concretude se lambuza de situações e pessoas em um mundo que gira em direções e alvos movediços. Parece que pouca coisa é inteiramente confiável e catalisadora de grandes unidades. A segurança está na solidez do que é transitório e imaterial e não existe maniqueísmo para a veloz mobilidade das coisas.

Mesmo reconhecendo que muitas coisas permanecem sólidas - ainda que se desmanchem no ar - velhos fenômenos globais e históricos como o racismo, o capitalismo, o machismo, o marxismo, a homofobia ou novos fenômenos econômicos e políticos como as guerras híbridas, as criptomoedas, a internet das coisas, etc. encontram-se permeadas de instáveis brutalidades que merecem necessárias reflexões sobre o início desse novo tempo. As grandes dicotomias: moderno/ antigo, universal/particular, analógico/digital, ho$\mathrm{mem} / \mathrm{mulher}$, esquerda/direita, feio/bonito, etc., convivem liquefeitamente como multiversos e antiversos de si mesmos. Outras coisas estão acontecendo para além das dicotomias.

Cidades cosmopolitas podem nos dar um retrato fiel dessas variações aproximais. Fazer parte de uma comunidade real ou virtual envolve um caráter poroso de negociação identitária. Ficou mais fácil assumir múltiplas identidades. Ao nos juntarmos a aliados e inimigos conforme nossas estratégias internas, acabamos por destruir qualquer possibilidade de destruição de um inimigo comum. Visitamos telas globais pensando na pureza frágil das nossas intenções, para depois sermos engolidos e liquidificados e nos tornamos iguais para os donos das telas. Parece que o nosso lugar já está demarcado e fazemos de conta que estamos empreendendo grandes mudanças. Analisamos e identificamos problemas estruturais e propomos, salvo algumas exceções, respostas tímidas e líquidas. 
Paradoxalmente, as identidades criam donos de assunto, de lugares e de modos de ser. Muitas vezes as exercemos para cumprir agendas de direitos e luta política, por vezes, apenas para entrar nas regras do mercado espetacular. No mundo do capital e do consumo, ser diferente é possuir uma identidade monetizável atenta às inovações trazidas pela indústria cultural. No mundo do pensamento que nega o capitalismo, ser diferente é ir de encontro às ideias líquidas que endeusam identidades e pertencimentos ao mercado globalizado. Mas não podemos deixar de reconhecer que quem critica o identitarismo, também o faz a partir da sua própria identidade. Surge, então, um questionamento: quais conceitos de pertencimento e identidade estão decidindo o que é o homem e a mulher na sociedade do século XXI? Qual é a minha tribo? E, se faço parte de uma, o que devo fazer com as outras identidades que possuo? Quando elas entram em conflito, quais os critérios para priorizá-las? Teríamos uma hermenêutica da identidade?

Este é um debate ruidoso. As identidades e certas categorias - religiosas, culturais, morais, étnicas/raciais, geográficas, partidárias, etc. - continuam a localizar na aparência e no modo de ser das pessoas a necessidade de exercer o poder que justifica a sua própria existência. É evidente que tais diferenças são acentuadas para legitimar o exercício dessa relação de controle e subserviência. Estamos numa quadra do tempo em que podemos nos imaginar realizando qualquer proeza indescritível no campo das ciências, dos afetos ou da indústria cultural. Tudo é aceitável como possibilidade de verdade. Podemos nos preparar para morar em Marte, nos comunicar por frequências holográficas, mudar de sexo, de posição política e de fé, pedir dinheiro nas redes para destruir os donos das redes, etc., porque as fronteiras estão abertas, e os nossos gestos mais banais nos vinculam a diversos modelos que se opõem entre si.

Nesse contexto, existem pessoas morrendo de fome e sendo assassinadas em razão da sua imagem, identidade e pertencimento. O que soa como um alerta, ora oportuno, ora estratégico, para aqueles que organizam propostas de mudanças estruturais, classistas e institucionais de caráter emancipatório para o planeta: A identidade nos leva ao debate do nacionalismo que, por sua vez, nos leva radicalmente para campos opostos de tirania e liberdade. Isso também tem soado como um alerta para os representantes do capital e da mídia nesse momento - algumas pessoas pensam que poderão ser salvas em razão de suas imagens e os usos que podem fazer delas. É possível ver o colorido risonho e oscilante das pessoas que, ao buscar a divulgação de seus projetos de mudanças mais profundos, pensam construir fortalezas contrahegemônicas, mas podem apenas estar traindo seus sólidos ou líquidos princípios e propósitos.

Sodré (1999), Carneiro (2005), Bauman (2008) e muitos outros dizem a mesma coisa de modos diferentes: a identidade só se realiza em razão das diferenças, e ela tanto oprime quanto liberta. Souza (1993) nos fala que uma das formas de exercer autonomia é possuir um discurso sobre si mesmo. Tudo isso apenas para afirmar que a ideia de liquidez, associada à ideia de identidade e pertencimento, está nos dando sinais de que algo surge para desencantar dois dos pilares do mundo moderno: a racionalidade e a certeza. Enfim, a inconstância, a dúvida e a virtualidade das coisas moldam o espírito desse novo tempo. O vírus e suas variantes mudam a certeza da vacina e os interesses de quem produz as doenças e os antídotos. Tudo é relativo. Tudo é efêmero. Nossas opiniões podem mudar daqui a um instante.

Então, o que nos liberta é liquidez ou a rigidez? E o que nos trai ocultamente e visivelmente em nome da nossa rigidez? Vamos ao shopping, compramos carros, roupas, bebidas, dinheiro, redes sociais das grandes marcas, e, depois, afirmamos ser anticapitalista e anti várias coisas, com uma instável calma liberal e um rápido arroto socializante. Ser igual é ser tradicional? Ser diferente é ser moderno? Ser diferente não é também ser tradicional e ser igual não é ser moderno? Na política, não tem sido a liquidez das ideias e ações que tem ganhado os debates? No consumo, não tem sido a rapidez e a digitalidade que têm pautado o mercado? No amor, não tem sido a celeridade e o simulacro que têm dado o tom das relações afetivas? E na guerra, não é a morte cirúrgica e sofisticada que tem sido a tendência? Estamos pautando um debate fora do lugar ou estamos sendo vencidos pela rigidez/liquidez dos conceitos? Temos que avaliar se estar aqui e em qualquer outro lugar, como sujeitos flexíveis e solúveis, é um vírus bom para enfrentarmos as consequências da globalização capitalista ou será o anúncio de uma nova barbárie. 


\section{Referências}

Bauman, Z. (2008). Vida para consumo: a transformação das pessoas em mercadorias (C. A. Medeiros, Trad.). Zahar.

Carneiro, S. (2005). A construção do outro como não-ser como fundamento do ser [Tese de doutorado, Universidade de São Paulo]. Repositório USP. https://repositorio.usp.br/ item/001465832
Sodré, M. (1999). Claros e Escuros, Identidade, Povo e Mídia. Vozes.

Souza, N. S. (1983). Tornar-se negro: as vicissitudes da identidade do negro brasileiro em ascensão social. Edições Graal. 